\title{
Human hybridoma technology
}

This article was published in the following Dove Press journal:

Antibody Technology Journal

30 August 2012

Number of times this article has been viewed

\section{Miroslaw K Gorny}

Department of Pathology, New York University Langone School of Medicine, New York, NY, USA

Correspondence: Miroslaw K Gorny Veterans Affairs Medical Center, Room I8I24N, 423 East 23rd Street, New York, NY I0010, USA Email mirek.gorny@nyumc.org
Abstract: In light of recent developments in the production of human monoclonal antibodies, particularly the method based on isolation of immunoglobulin genes from antigen-specific B cells, the hybridoma technology has become obsolete to some extent. However, the method requires a relatively simple procedure at a low cost and has inherently valuable features, including continuous production of the whole molecule of specific antibodies that retain their native structure. Furthermore, several technical improvements, including accessibility to a panel of various partner cells, enhanced Epstein-Barr virus transformation and optimized electroporation, have increased the fusion efficiency for production of hybrids. Finally, a hybridoma-produced monoclonal antibody $(\mathrm{mAb})$ can be used to test whether certain functions of a recombinant $\mathrm{mAb}$, produced by molecular techniques from the same clone of $\mathrm{B}$ cells, correspond to the native antibodies. Access to several different methods of $\mathrm{mAb}$ production, including hybridoma technology, potentiates our capability to understand the human immune response to various invading pathogens and tumors with the perspective of using the antibodies for diagnosis and therapy.

Keywords: hybridoma, human monoclonal antibody, B cells

\section{Introduction}

Several methods are available for production of human monoclonal antibodies (mAbs), including hybridoma technology, Epstein-Barr virus (EBV) transformation, phagedisplay libraries, transgenic mice carrying human immunoglobulin (Ig) loci, and molecular techniques based on isolation of Ig genes from antigen-specific B cells. Each of these methods has some advantages and limitations, which determine their usage for certain purposes.

The most efficient method is single-B-cell polymerase chain reaction technology, which may produce a number of recombinant $\mathrm{mAbs}$, including both unique and clonal antibodies. ${ }^{1,2}$ A large panel of such mAbs made possible the study of the repertoire of the human antibody response to HIV-1.,4 The phage-display libraries can generate Fab fragments with randomly paired heavy and light chains, but with high affinity, which makes the mAbs suitable for various applications, including therapy. ${ }^{5}$ Transgenic mice can be used for studying the human antibody response to a particular antigen and for the production of human mAbs with desired specificity for clinical applications. ${ }^{6}$

The standard hybridoma technology, which was invented by Kohler and Milstein, ${ }^{7}$ produces mAbs by fusion of antibody-producing cells with myeloma cells. This method has been successfully used in our group for the production of human antiHIV-1 mAbs derived from infected individuals, which were used for studies of their submit your manuscript $\mid$ www.dovepress.com

Dovepress

http://dx.doi.org// 0.21 47/ANTI.S30489
Antibody Technology Journal 2012:2 I-5

(C) 2012 Gorny, publisher and licensee Dove Medical Press Ltd. This is an Open Access article which permits unrestricted noncommercial use, provided the original work is properly cited. 
neutralizing activities and the structural analysis of antigens, using crystallographic methods. ${ }^{8-13}$ Studies of a panel of 51 human mAbs against the HIV-1 V3 region revealed the spectrum of the antibody response to V3 in HIV-1-infected individuals as well as the preferential usage of the $\mathrm{V}_{\mathrm{H}} 5-51$ and VL lambda genes by mAbs specific to one particular conserved core epitope. ${ }^{14,15}$

Hybridoma technology has several appealing features, including a relatively simple protocol, low costs, and the ability to immortalize antibody-producing cells that were either stimulated or transformed by EBV. Hybridoma mAbs retain their native structure, including the variable and constant Ig fragments, which is important in tests that measure Fc-mediated activities; for example, antibody-dependent cellular cytotoxicity, which depends on the polymorphism of the Fc fragment. Furthermore, a mAb generated by hybridoma methods can be used to compare its compatibility, in terms of sequence and functions, with a recombinant $\mathrm{mAb}$ produced by molecular techniques using the same clone of B cells. ${ }^{16}$ The major disadvantage of the hybridoma method is low fusion efficiency, resulting in a limited number of mAbs produced per experiment; however, several technical modifications make this method more efficient.

\section{Standard hybridoma technology}

The original hybridoma method was invented to continuously produce mouse antibodies with the desired specificity against a particular epitope. ${ }^{7}$ The production of antibodies by spleen B cells obtained from immunized mice was immortalized by fusion with cancerous myeloma cells. This standard hybridoma technology was utilized for generation of human mAbs from B lymphocytes using peripheral blood mononuclear cells (PBMCs) from individuals infected with various pathogens or from cancer patients. The method has several elements that are important for the successful production of mAbs.

\section{Human B lymphocytes}

Antigen-specific B cells are rarely present in circulation, ${ }^{17}$ and in combination with a low fusion efficiency, this results in a limited number of mAbs produced in a particular experiment. Therefore, selection of a proper blood donor is critical for this method. A high titer of serum antibodies may not always correlate with an increased number of corresponding peripheral B cells, but is indicative of a greater chance of successful production of mAbs.

Unstimulated human peripheral B lymphocytes are rarely used, although it was shown that they can be fused with human myeloma or lymphoblastoid cell lines and produce mAbs. ${ }^{18,19}$ Stimulation of B cells substantially increases the fusion efficiency and development of mAbs. The most commonly used method is the infection and transformation of B cells by EBV, the method invented by Steinitz et al to produce human antibody specific to the synthetic hapten NNP. ${ }^{20}$ This method has been successfully used for production of human mAbs against various antigens, including HIV-1.21

The culture supernatant of the B95-8 marmoset cell line, established by Miller et al, ${ }^{22}$ contains EBV, which infects human B cells by binding to complement receptor 2 (CD21) and transforms them over a period of 1-2 weeks in culture, forming clumps of lymphoblastoid cells clearly visible under the microscope. The EBV transformation of PBMCs requires the use of cyclosporin $\mathrm{A}$ in the culture media to suppress EBV-specific cytotoxic T cells, present in almost all human donors, as they may eliminate EBV-transformed cells in culture in vitro. ${ }^{23}$

The EBV transformation of human B cells can be increased by activation of the B cells by an oligodeoxynucleotide containing the $\mathrm{CpG}$ motif, which acts as a Tolllike receptor-9 agonist. ${ }^{24-26}$ The EBV alone transforms only a small population of $\mathrm{B}$ cells, but upon $\mathrm{CpG}$ activation, the efficiency of transformation is increased from 1\%-2\% to $30 \%-100 \%$ of B lymphocytes. ${ }^{26}$ The method of $\mathrm{CpG}$ enhancement of EBV transformation of memory B cells was used to produce mAbs against severe acute respiratory syndrome coronavirus (SARS-CoV). ${ }^{26}$

The EBV-transformed cells, however, are not cancerous cells, as they do not form tumors upon inoculation into severe combined immunodeficiency (SCID) mice, and as such cannot continuously grow and synthesize antibodies due to cell senescence. The problem of losing the ability of antibody production can be overcome by freezing aliquots of EBVtransformed cells at their early stage of development and then expansion of the cells in culture as long as they continue to produce $m A b s$. The other possibility is the immortalization of lymphoblastoid clones producing mAbs of interest by fusion with myeloma cells to generate hybridoma cell lines.

\section{Partner cells for fusion}

There are several myeloma cell lines suitable for fusion with human B cells and available at the American Type Culture Collection. Two of these cell lines, SHM-D $33^{27}$ and HMMA $2.5,{ }^{28}$ are frequently used for production of human mAbs. These cell lines are a nonsecreting mouse $\times$ human heteromyeloma that is resistant to ouabain and produces stable hybridomas upon fusion with human EBV-transformed B cells. 
The heteromyeloma SHM-D33 was used in our laboratory for the production of more than 100 human mAbs against HIV-1 envelope proteins and parvovirus B19. ${ }^{14,15,29-35}$ The cell line HMMA 2.5 was compared with six other myeloma cell lines using electrofusion and achieved the highest fusion efficiency. ${ }^{24}$ This cell line was also used for production of HIV-1 mAbs. ${ }^{36}$

\section{Feeder cells}

Various lymphoid cells producing cytokines supporting the growth and cloning of hybrids can be used as a feeder layer. Mouse peritoneal washed cells, containing macrophages, were used in the past and recently replaced by commercially available supplements. GK5 cells, human myeloma cells, ${ }^{37}$ successfully used in our laboratory for cloning of hybrids, ${ }^{23}$ were replaced by irradiated PBMCs from healthy donors. Hybridoma cells can be cloned also without feeder cells, even at one cell per well in 96-well plates, with slightly lower cloning efficiency, but the surviving hybrids are very stable and usually good producers of mAbs.

\section{Fusion}

This is accomplished mainly by using polyethylene glycol (PEG) or by electrofusion. The mechanism of PEG-mediated fusion is not well known, but it has been suggested that it may dehydrate the lipid headgroups, leading to asymmetry of the membrane bilayer, which favors fusion of two cells. ${ }^{38}$ The procedure is relatively simple, as PEG is added dropwise to the cell pellet and then removed by several washings to avoid its toxicity. The main problem is a low efficiency of fusion, which is around $10^{-5}$ based on relative measure, ie, the number of hybridomas per $10^{5} \mathrm{~B}$ cells; this can be partly overcome by using an increased number of $\mathrm{B}$ cells or EBV-transformed cells.

Using electrofusion, the membranes of neighboring cells are joined by the application of a pulsed electrical field; an alternating current is used for alignment of cells, and then the cells are electroporated with high-voltage direct-current pulse. ${ }^{24,39}$ In a recent study that optimized the electrofusion conditions, its efficiency was increased to $0.43 \%$ (or $4 \times 10^{-4}$ ) and was approximately five to ten times more efficient than PEG in the formation of hybrid colonies, as reported by Yu et al. ${ }^{24}$ Electrofusion parameters require optimization for the particular cells being used, both human B cells and partner cells. ${ }^{24}$

Fusion results in the formation of three types of hybrids $-\mathrm{B}$ cell $\times$ B cell, B cell $\times$ partner (myeloma) cell, and partner $\times$ partner cell - and also yields some unfused $\mathrm{B}$ cells and partner cells. The hybridoma of interest is a B cell $\times$ partner cell, which is selected using medium containing hypoxanthine-aminopterin-thymidine (HAT), while unfused B cells and B cell $\times$ B-cell hybrids die due to their short life span. If EBV-transformed B cells are used for fusion, ouabain is then added to the medium, which kills the unfused transformed B cells. Ouabain is a cardiac glycoside that inhibits the plasma membrane sodium pump and can also selectively induce apoptosis in transformed cells, but not in PBMCs.

The partner cells for fusion are deficient for the hypoxanthine-guanine phosphoribosyltransferase (HGPRT) gene, rendering them sensitive to aminopterin, which inhibits the nucleotide synthesis by the de novo pathway. These cells turn to an alternative salvage pathway, which is encouraged by providing hypoxanthine and thymidine, both included in HAT. As the B cells are using the salvage pathway because they have the HGPRT enzyme, only hybridoma B cell $\times$ partner cell can survive in HAT medium and grow into clones producing monoclonal antibody. The unfused myeloma cells cannot survive, because they do not have the ability to synthesize nucleotides by the de novo or salvage pathways.

Fusion between EBV-transformed B cells and partner cells became the standard for production of hybridomas. The original fusion was performed between the human EBVtransformed clone, B6, producing antibodies against tetanus toxoid and the human B-cell line KR-4. The results showed that the resulting hybridomas were more stable, produced higher cloning efficiency, and secreted more antibodies compared to the untransformed B6 cells. ${ }^{40}$ The high cloning efficiency of hybridoma cells, which can be cloned at one cell per well, is particularly important, as EBV-transformed cells exhibit some chromosomal instability and their cloning is difficult, requiring at least a few cells per well, even in the presence of feeder cells. ${ }^{41}$

\section{Screening}

The screening system is dependent on the antigen to be used. Binding of antibodies to soluble antigens, including peptides and proteins, is most frequently determined by enzyme-linked immunosorbent assay (ELISA), which has a sensitivity of detection of $0.001 \mu \mathrm{g} / \mathrm{mL}$. Some short peptides should be used as biotinylated and immobilized on streptavidin-coated plates for more optimal exposure to antibodies during ELISA. Screening by a functional assay reduces the time involved in the laborious process of development; for example, neutralizing human mAbs. We have used, for the first time, the TZM-bl cell neutralizing assay for screening and production of mAb 2909, which has exceptionally high neutralizing 
activity against HIV-1 ${ }_{\text {SF } 162}$ and unusual characteristics. This $\mathrm{mAb}$ does not bind to monomeric proteins or peptides by ELISA, but it binds to intact virions because it recognizes a complex quaternary epitope, containing elements of V2 and V3 loops, present only on the virus surface. ${ }^{42}$

In conclusion, hybridoma technology is still useful for production of human mAbs due to its relatively simple procedure and low cost and the ability to immortalize B cells that continuously produce specific antibodies retaining their native structure. For the successful generation of hybridomas, the antigen-specific expanded clones of EBV-transformed human $\mathrm{B}$ cells activated by $\mathrm{CpG}$ should be fused with heteromyeloma cells using either PEG or optimized electrofusion.

\section{Acknowledgments}

This work was supported by the NIH grant AI091543. The author would like to thank Constance Williams for her help in the preparation of this manuscript.

\section{Disclosure}

The author discloses no conflicts of interest.

\section{References}

1. Tiller T, Meffre E, Yurasov S, Tsuiji M, Nussenzweig MC, Wardemann H. Efficient generation of monoclonal antibodies from single human B cells by single cell RT-PCR and expression vector cloning. J Immunol Methods. 2008;329(1-2):112-124.

2. Liao HX, Levesque MC, Nagel A, et al. High-throughput isolation of immunoglobulin genes from single human B cells and expression as monoclonal antibodies. J Virol Methods. 2009;158(1-2):171-179.

3. Scheid JF, Mouquet H, Feldhahn N, et al. Broad diversity of neutralizing antibodies isolated from memory B cells in HIV-infected individuals. Nature. 2009;458(7238):636-640.

4. Scheid JF, Mouquet H, Ueberheide B, et al. Sequence and structural convergence of broad and potent HIV antibodies that mimic CD4 binding. Science. 2011;333(6049):1633-1637.

5. Throsby M, van den Brink E, Jongeneelen M, et al. Heterosubtypic neutralizing monoclonal antibodies cross-protective against $\mathrm{H} 5 \mathrm{~N} 1$ and $\mathrm{H} 1 \mathrm{~N} 1$ recovered from human IgM+ memory B cells. PLoS One. 2008;3(12):e3942.

6. He Y, Honnen WJ, Krachmarov CP, et al. Efficient isolation of novel human monoclonal antibodies with neutralizing activity against HIV-1 from transgenic mice expressing human Ig loci. J Immunol. 2002;169(1):595-605.

7. Kohler G, Milstein C. Continuous cultures of fused cells secreting antibody of predefined specificity. Nature. 1975;256(5517): 495-497.

8. Burke V, Williams C, Sukumaran M, et al. Structural basis of the cross-reactivity of genetically related human anti-HIV-1 monoclonal antibodies: implications for design of V3-based immunogens. Structure. 2009;17(11):1538-1546.

9. Jiang X, Burke V, Totrov M, et al. Conserved structural elements in the V3 crown of HIV-1 GP120. Nat Struct Mol Biol. 2010;17(8): 955-961.

10. Spurrier B, Sampson J, Totrov M, et al. Structural analysis and computational modeling of human and macaque monoclonal antibodies provide a model for the quaternary neutralizing epitope of HIV-1 gp120. Structure. 2011;19(5):691-699.
11. Gorny MK, Sampson J, Li H, et al. Human anti-V3 HIV-1 monoclonal antibodies encoded by the VH5-51/VL lambda genes define a conserved antigenic structure. PLoS One. 2011;6(12):e27780.

12. Gorny MK, Conley AJ, Karwowska S, et al. Neutralization of diverse HIV-1 variants by an anti-V3 human monoclonal antibody. J Virol. 1992;66(12):7538-7542.

13. Hioe CE, Wrin T, Seaman MS, et al. Anti-V3 monoclonal antibodies display broad neutralizing activities against multiple HIV-1 subtypes. PLoS One. 2010;5(4):e10254.

14. Gorny MK, Xu JY, Karwowska S, Buchbinder A, Zolla-Pazner S. Repertoire of neutralizing human monoclonal antibodies specific for the V3 domain of HIV-1 gp120. J Immunol. 1993;150(2):635-643.

15. Gorny MK, Wang XH, Williams C, et al. Preferential use of the VH5-51 gene segment by the human immune response to code for antibodies against the V3 domain of HIV-1. Mol Immunol. 2009;46(5):917-926.

16. Bonsignori M, Hwang KK, Chen X, et al. Analysis of a clonal lineage of HIV-1 envelope V2/V3 conformational epitope-specific broadly neutralizing antibodies and their inferred unmutated common ancestors. J Virol. 2011;85(19):9998-10009.

17. Stevens RH, Macy E, Morrow C, Saxon A. Characterization of a circulating subpopulation of spontaneous antitetanus toxoid antibody producing B cells following in vivo booster immunization. J Immunol. 1979;122(6):2498-2504.

18. Houghton AN, Brooks H, Cote RJ, Taormina MC, Oettgen HF, Old LJ. Detection of cell surface and intracellular antigens by human monoclonal antibodies. Hybrid cell lines derived from lymphocytes of patients with malignant melanoma. $J$ Exp Med. 1983;158(1):53-65.

19. Glassy MC, Handley HH, Hagiwara H, Royston I. UC 729-6, a human lymphoblastoid B-cell line useful for generating antibodysecreting human-human hybridomas. Proc Natl Acad Sci U S A. 1983; 80(20):6327-6331.

20. Steinitz M, Klein G, Koskimies S, Makel O. EB virus induced B lymphocyte cells lines producing specific antibody. Nature. 1977;269(5627):420-422.

21. Robinson JE Jr, Holton D, Pacheco-Morell S, Liu J, McMurdo H. Identification of conserved and variant epitopes of human immunodeficiency virus type 1 (HIV-1) gp120 by human monoclonal antibodies produced by EBV-transformed cell lines. AIDS Res Hum Retroviruses. 1990;6(5):567-569.

22. Miller G, Shope T, Lisco H, Stitt D, Lipman M. Epstein-Barr virus: transformation, cytopathic changes and viral antigens in squirrel, monkey and marmoset leukocytes. Proc Natl Acad Sci U S A. 1972;69(2):383-387.

23. Gorny MK. Production of human monoclonal antibodies via fusion of Epstein-Barr virus-transformed lymphocytes with heteromyeloma. In: Celis JE, editor. Cell Biology: A Laboratory Handbook. Waltham: Academic Press; 1994;2:276-281.

24. Yu X, McGraw PA, House FS, Crowe JE Jr. An optimized electrofusion-based protocol for generating virus-specific human monoclonal antibodies. J Immunol Methods. 2008;336(2):142-151.

25. Hartmann G, Krieg AM. Mechanism and function of a newly identified CpG DNA motif in human primary B cells. J Immunol. 2000;164(2):944-953.

26. Traggiai E, Becker S, Subbarao K, et al. An efficient method to make human monoclonal antibodies from memory B cells: potent neutralization of SARS coronavirus. Nat Med. 2004;10(8):871-875.

27. Teng NN, Lam KS, Calvo Riera F, Kaplan HS. Construction and testing of mouse-human heteromyelomas for human monoclonal antibody production. Proc Natl Acad Sci U S A. 1983;80(23):7308-7312.

28. Posner MR, Elboim H, Santos D. The construction and use of a human-mouse myeloma analogue suitable for the routine production of hybridomas secreting human monoclonal antibodies. Hybridoma. 1987;6(6):611-625.

29. Gorny MK, VanCott TC, Hioe C, et al. Human monoclonal antibodies to the V3 loop of HIV-1 with intra- and interclade cross-reactivity. $J$ Immunol. 1997;159(10):5114-5122. 
30. Gorny MK, VanCott TC, Williams C, Revesz K, Zolla-Pazner S. Effects of oligomerization on the epitopes of the human immunodeficiency virus type 1 envelope glycoproteins. Virology. 2000;267:220-228.

31. Gorny MK, Williams C, Volsky B, et al. Human monoclonal antibodies specific for conformation-sensitive epitopes of V3 neutralize HIV-1 primary isolates from various clades. J Virol. 2002;76(18): 9035-9045.

32. Gorny MK, Williams C, Volsky B, et al. Cross-clade neutralizing activity of human anti-V3 monoclonal antibodies derived from the cells of individuals infected with non-B clades of HIV-1. J Virol. 2006;80(14):6865-6872.

33. Jeffs SA, Gorny MK, Williams C, et al. Characterization of human monoclonal antibodies selected with a hypervariable loop-deleted recombinant HIV-1(IIIB) gp120. Immunol Lett. 2001;79(3):209-213.

34. Xu JY, Gorny MK, Palker T, Karwowska S, Zolla-Pazner S. Epitope mapping of two immunodominant domains of gp41, the transmembrane protein of human immunodeficiency virus type 1 , using ten human monoclonal antibodies. J Virol. 1991;65:4832-4838.

35. Gigler A, Dorsch S, Hemauer A, et al. Generation of neutralizing human monoclonal antibodies against parvovirus B19 proteins. JVirol. 1999;73(3):1974-1979.
36. Cavacini L, Duval M, Song L, et al. Conformational changes in env oligomer induced by an antibody dependent on the V3 loop base. AIDS. 2003;17(5):685-689.

37. Satoh J, Prabhakar BS, Haspel MV, Ginsberg-Fellner F, Notkins AL. Human monoclonal autoantibodies that react with multiple endocrine organs. N Eng J Med. 1983;309(4):217-220.

38. Lentz BR. Polymer-induced membrane fusion: potential mechanism and relation to cell fusion events. Chem Phys Lipids. 1994;73(1-2): 91-106.

39. Zimmermann U. Electric field-mediated fusion and related electrical phenomena. Biochim Biophys Acta. 1982;694(3):227-277.

40. Kozbor D, Lagarde AE, Roder JC. Human hybridomas constructed with antigen-specific, EBV-transformed cell lines. Proc Natl Acad Sci US A. 1982;79(21):6651-6655.

41. Roder JC, Cole SP, Kozbor D. The EBV-hybridoma technique. Methods Enzymol. 1986;121:140-167.

42. Gorny MK, Stamatatos L, Volsky B, et al. Identification of a new quaternary neutralizing epitope on human immunodeficiency virus type 1 virus particles. J Virol. 2005;79(8):5232-5237.
Antibody Technology Journal

\section{Publish your work in this journal}

Antibody Technology Journal is international, peer-reviewed, open access journal publishing original research, reports, reviews and commentaries on all areas of antibody technology. The manuscript management system is completely online and includes a very quick and fair

\section{Dovepress}

peer-review system. Visit http://www.dovepress.com/testimonials.php to read real quotes from published authors. 